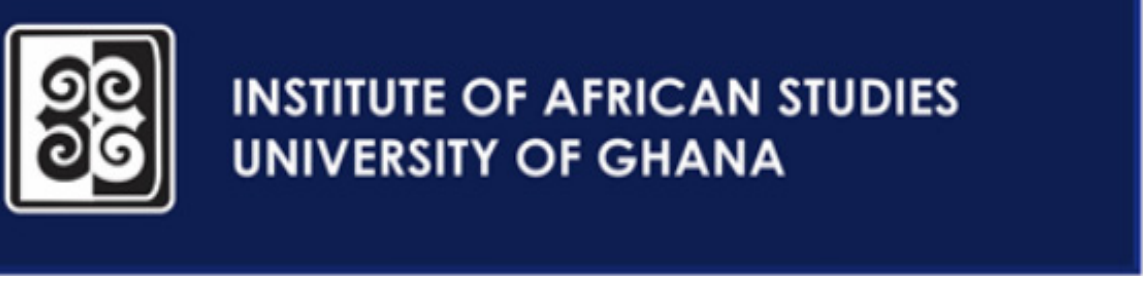

Contemporary Journal of African Studies 2019; 6 (1): 76-95

https://dx.doi.org/10.4314/contjas.v6i1.5

ISSN 2343-6530

(C) 2019 The Author(s)

Open Access article distributed under the terms of the

Creative Commons License [CC BY-NC-ND 4.0]

http://creativecommons.org/licenses/by-nc-nd/4.0

\title{
Dutch Reformed Church mission education and its secular reconstruction/transformation by the Bakgatla ba Kgafela African community of Rustenburg, South Africa, c.1903 - 1930s
}

\section{Bernard K. Mbenga}

\section{Professor of History, North-West University, Mafikeng Campus, South Africa Author's email: Bernard.Mbenga@nwu.ac.za}

\begin{abstract}
The paper analyses the nature of Dutch Reformed Church (DRC) mission education among the Bakgatla ba Kgafela of the Rustenburg District, South Africa. The emphasis of education was religious. A senior DRC missionary expressed the aim of education succinctly: "The purpose of education is to develop understanding, empathy and to win the children for Jesus Christ" (Maree, 1966: 65-66). The Bakgatla resented this racist policy, calling for the broadening of the curriculum, but unsuccessfully. Consequently, they built their own school. Teachers were recruited from some of the then prestigious educational institutions in South Africa, e.g. Tiger Kloof. The community funded teachers' salaries and other expenses. The new school, named 'Ramolope,' after a local family patriarch who spearheaded its building, opened in the early 1920s. Radically different from the DRC school, it emphasised English, Mathematics and Science. It became enormously popular in the region. Some of the DRC mission pupils were leaving, to join the new school! Neighbouring communities began to copy the Bakgatla's successful transformational model. This competition so upset the DRC missionaries that they excommunicated all the adult (DRC) Christian members of the Ramolope family. Eventually, the government took over the funding of the school.
\end{abstract}

Keywords: Bakgatla, Pilanesberg, Dutch Reformed Church, Saulspoort, missionaries, colonialism 


\title{
Dutch Reformed Church mission education and its secular reconstruction/transformation by the Bakgatla ba Kgafela African community of Rustenburg, South Africa, c.1903 - 1930s
}

\author{
Bernard K. Mbenga
}

\begin{abstract}
The paper analyses the nature of Dutch Reformed Church (DRC) mission education among the Bakgatla ba Kgafela of the Rustenburg District, South Africa. The emphasis of education was religious. A senior DRC missionary expressed the aim of education succinctly: "The purpose of education is to develop understanding, empathy and to win the children for Jesus Christ" (Maree, 1966: 65-66). The Bakgatla resented this racist policy, calling for the broadening of the curriculum, but unsuccessfully. Consequently, they built their own school. Teachers were recruited from some of the then prestigious educational institutions in South Africa, e.g. Tiger Kloof. The community funded teachers' salaries and other expenses. The new school, named 'Ramolope,' after a local family patriarch who spearheaded its building, opened in the early 1920s. Radically different from the DRC school, it emphasised English, Mathematics and Science. It became enormously popular in the region. Some of the DRC mission pupils were leaving, to join the new school! Neighbouring communities began to copy the Bakgatla's successful transformational model. This competition so upset the DRC missionaries that they excommunicated all the adult (DRC) Christian members of the Ramolope family. Eventually, the government took over the funding of the school.
\end{abstract}

Keywords: Bakgatla; Pilanesberg; Dutch Reformed Church; Saulspoort; missionaries; colonialism.

\section{Résumé}

L'article analyse la nature de l'éducation missionnaire de l'église Dutch Reformed Church [Eglise réformée hollandaise] (RDC) chez les Bakgatla ba Kgafela du district de Rustenburg, en Afrique du Sud. L'éducation fut focalisée sur l'élément religieux. Un missionnaire supérieur de la RDC résuma clairement l'objectif de l'éducation en ces mots: «L'objectif de l'éducation est de développer la compréhension et l'empathie et de gagner les enfants pour Jésus-Christ» (Maree, 1966: 65-66). Les Bakgatla rejetèrent cette politique raciste tout en réclamant l'élargissement du programme, mais sans succès. En conséquence, ils construisirent leur propre école. Les enseignants furent recrutés dans des institutions d'enseignement prestigieuses en Afrique du Sud, par exemple, Tiger Kloof. La communauté finança les salaires et les autres dépenses des enseignants. La nouvelle école, dénommée 'Ramolope ', le nom d'un patriarche issu de la famille qui en dirigea la construction, ouvrit ses portes au début des années 1920. Radicalement différente de l'école de la RDC, elle mit l'accent sur l'anglais, les mathématiques et les sciences. En conséquence, elle devint extrêmement reconnue dans la région. Certains élèves de la

https://dx.doi.org/10.4314/contjas.v6i1.5

Bernard K. Mbenga (Bernard.Mbenga@nwu.ac.za) is a Professor of History at the North-West University, Mafikeng Campus in South Africa. He is the co-author and co-editor (with Hermann Giliomee) of New History of South Africa (Tafelberg: Cape Town, November 2007). He has jointly (with Andrew Manson) authored "People of the Dew": The Bafokeng of the Phokeng-Rustenburg District of South Africa, from Early Times to 2000, (Jacana Media: Johannesburg, 2010). He has also co-authored and co-edited (with Carolyn Hamilton and Robert Ross), The Cambridge History of South Africa, Vol. I, From Early Times to 1885 (Cambridge University Press: London, 2010). He is the co-author (with Andrew Manson) of Land, Chiefs, Mining: South Africa's North West Province Since 1840 (Wits University Press: Johannesburg, 2014) and with Andrew Manson and Ariana Lissoni, A Short History of the ANC in the North West Province From 2009 (Unisa Press: Pretoria, 2016). 
mission de la RDC partirent pour s'inscrire dans la nouvelle école! Les communautés voisines commencèrent à copier le modèle transformationnel réussi de Bakgatla. Cette concurrence bouleversa les missionnaires de la RDC tellement que qu'ils excommunièrent tous les membres chrétiens adultes (de la RDC) de la famille Ramolope. Enfin, le gouvernement reprit le financement de l'école.

Mots-clés: Bakgatla; Pilanesberg; Dutch Reformed Church [Église réformée hollandaise];

Saulspoort; missionnaires; colonialisme.

\section{Introduction}

This paper is about the Bakgatla ba ga Kgafela ${ }^{1}$, a Setswana-speaking African community of the Pilanesberg region of the Rustenburg District situated in today's North-West Province of South Africa. The Bakgatla live in an area bounded by the rivers Odi (Crocodile), Madikwe (Marico) and Kgetleng (Elands), where they have lived since at least the $17^{\text {th }}$ century A.D. Between 1820 and 1840, the Bakgatla, like the rest of Batswana groups in the Pilanesberg, were invaded by forces from outside the Pilanesberg, namely, the Bafokeng of Chief Sebitloane, the Ndebele of Mzilikazi and lastly the Voortrekkers, in that order. Bafokeng and Ndebele conquests were relatively short-lived as they both soon left the region and headed northwards where they founded new kingdoms. The Voortrekkers ${ }^{2}$, however, having conquered the Batswana ethnic groups in the Pilanesberg in 1837, declared the entire western Transvaal as theirs by right of conquest, and all the Africans in it their colonial subjects (Mbenga, 1996:33-45).

The objectives of this paper are two-fold: First, it explores and analyses the nature of Dutch Reformed Church (DRC) mission education among the Bakgatla. It then explains why the Bakgatla became disenchanted with mission education and, therefore, established their own school which would provide the kind of education they wanted their children to acquire. Second, the paper adds to the considerable literature on the education of African children in colonial Africa generally, and colonial South Africa specifically.

There is a lot of published literature on missionary activity among the various African peoples of South Africa generally, but which can be read elsewhere (for example, Elphic and Davenport, 1997).

The rudiments of Western education were introduced into African societies generally by European missionaries. DRC missionary activity among black societies in South Africa dates back to the 17th century when the church's first missionaries worked among the Khoikhoi and enslaved persons at the Cape. With the founding of the South African Missionary Society in 1799, DRC interest and involvement in missionary work began to spread northwards. This northward expansion also saw the emergence of two

\footnotetext{
${ }^{1}$ Hereafter, 'Bakgatla.' For a detailed history of the Bakgatla-ba-Kgafela, see Schapera, 1942.

${ }^{2}$ The Voortrekkers were subsequently called the Boers, and later still, the Afrikaners, the name they are currently known by. Although a racial minority, they are the most numerous of the white population groups in South Africa today.
} 
features. First, separate churches, based on race, were formed within the DRC. Second, there was a greater missionary involvement among blacks beyond South Africa's northern borders. During the latter part of the $19^{\text {th }}$ century, therefore, the Cape Synod of the DRC began to establish missions in almost all the central African countries and beyond. ${ }^{3}$

In order to appreciate the objectives of missionary education among Africans, we first have to look into the missionaries' purpose in spreading Christianity. The general missionary view of African culture was that it was fundamentally corrupt, sinful and needed to be redeemed. Two examples of this view will suffice. At the turn of the 19th century, in what was to become Northern Rhodesia (now Zambia), as Rotberg has recorded, missionaries condemned African culture as an "unfathomable abyss of corruption and degradation" and consciously sought to transform all aspects of African culture (Rotberg, 1965: 338-341). In South Africa during the 1830s, the Wesleyans among the Amaxhosa people assumed that "their listeners had no consciousness of evil nor prohibitions against wrongful conduct" (Fast, 1991: 84).

For these reasons, therefore, evangelisation came as part of a total "package" to transform African culture. As Comaroff has explained, 19th century Christian evangelisation, which he terms the "civilizing colonialism of the mission," was one of three competing models of colonialism, the other two being "state colonialism" of the British administrators at the Cape, and the "settler colonialism" of the Boers (Comaroff, 1989: 674). ${ }^{4}$ Comaroff also states that the basic purpose of the missionaries' "civilizing colonialism" was "to reconstruct totally African society and culture," by encouraging Africans to adopt European modes of thought and life such as, for example, "individualism and the nuclear family, of private property and commerce..." and taking practical steps to implant them in African society (Comaroff, 1989: 673; Hutchinson, 1957: 160). In other words, African culture was intended to approximate that of contemporary Europe. Only then, the missionaries considered, would the Africans be receptive to their "civilizing mission." (Comaroff, 1991: 8-14; Hutchinson, 1957: 160, 162-163).

Missionaries, therefore, frowned upon and actively suppressed many aspects of African culture, such as initiation ceremonies and polygamy. The DRC missionaries, for example, actively discouraged bogwera (circumcision), which they regarded as "most immoral[,] and did all they could to stamp it

\footnotetext{
${ }^{3}$ For details of this missionary expansion, see, for example, du Toit, 1984: 617 - 620; Fast, 1991; Jordaan, 1962 : 273 - 275. The very first organised efforts at missionary work in South Africa began in 1737 when the Moravians sent a missionary to the Khoikhoi but had to withdraw in the face of DRC opposition and desire for their desire for religious monopoly of the Cape. In the late 1700 s, there were brief attempts by van der Kemp and J. Williams among the Ngqika, while the London Missionary Society's (LMS) initial efforts were among the Griqua, the Korana and the southern Batswana.

${ }^{4}$ Emphasis in text. For details of these models of colonialism, see this same source, pp. $671-675$.
} 
out" (Schapera, 1938: 106-108; Grant, 1984: 7-17). In particular, cultural activities that were expressed in physical, bodily form, such as dancing, were actively discouraged by the missionaries (Hofmeyr, 1991: 643; Schapera, 1958: 2; Dachs, 1972: 648). This then was the contemporary missionary context into which the pioneer missionary among the Bakgatla, Henri Louis Gonin, landed and embraced.

In 1860, Gonin, a Swiss national was recruited by the DRC for missionary work in South Africa, while he was still doing theological training in Geneva and Edinburgh. He and his wife arrived in the Rustenburg district in the then western Transvaal in May 1862 (Mbenga, 1996: 50-51). ${ }^{5}$ Following approval by the highest political authority in Rustenburg, Commandant Paul Kruger (later President of the Transvaal), and acceptance by the Bakgatla chief, Kgamanyane, Gonin began work as a missionary among the Bakgatla. In June 1864, the Gonins bought the farm Welgeval (or Welgevallen), close to Saulspoort the capital of Chief Kgamanyane in the Pilanesberg. The following month the Gonins shifted to Welgeval and soon began to preach and conduct Sunday service there (Mbenga, 1996: 53-55).

\section{The wider ideological context}

To understand the nature of missionary education in the DRC schools in the Pilanesberg we need to situate it in the wider ideological thinking and discourse among colonial Boer government officials, missionaries and the general white populace in South Africa in the late $19^{\text {th }}$ and early $20^{\text {th }}$ centuries.

The Grondwet (constitution) of the South African Republic (SAR) established by the Boers had decreed inequality between blacks and whites (Eybers, 1918: xix) but, nevertheless, did not spell this out with regard to education. Black children in the Transvaal generally attended mission schools since "Native education was exclusively a mission venture" (Linington, 1933: 238). By 1896, according to the educational historian, Cross, some African children even attended schools with white or mixed-race children (Cross, 1987: 266). However, this was set to change, as we will see below.

The beginning of the twentieth century saw South Africa emerge from the highly destructive South African War (SAW) of 1899 - 1902 between the British and the Boers which ended in the defeat of the latter and a peace settlement in April 1902 (Marks, 2011). The immediate post-war period, therefore, was one of reconstruction, a process initiated and overseen by the new British administration led by Alfred Milner. The immediate post-war period was, in fact, about reconstructing all areas of South African national

\footnotetext{
${ }^{5}$ Gonin belonged to the Buitelandse Sending (i.e. Foreign Mission) branch which fell under the Foreign SubCommittee of the N.G. Kerk of South Africa. This was the part of the church that catered for Africans in the Transvaal, Bechuanaland Protectorate, Mashonaland and Nyasaland.
} 
life, including African education. The underlying assumption of the development policy of the Milner regime was "that South Africa is a 'white man's country' in the sense that the 'white man should rule,' on the grounds of his "superior civilisation"' (Cross, 1992: 117). With this thinking in mind, in December 1901, Milner is reported to have stated: "I think ... that much more should be done for education of the natives than has been attempted ... I do not mean that they should be educated like Europeans, for their requirements and capacities are very different ..." (Ibid, 119). Therefore, education for blacks, as Milner had envisaged in December 1901, would necessarily have to be different from, and lower than, that of Europeans because "their [African] requirements and capacities are very different..." (Cross, 1987: 263). This meant that separate and, by implication, inferior African educational institutions would cater for "their natural aptitudes for their own good and that of the [African] community" (ibid).

Milner's ideas of a racially segregated and inferior education for Africans were partly his own, but partly from the South African Native Affairs Commission (SANAC) of 1903-1905 which he had appointed to make recommendations for a comprehensive "native policy." In this regard, the SANAC emphasised, among other issues, "moral and religious instruction" for African pupils and also recommended, for example, that "industrial training and instruction in manual work are of particular advantage to the Native in fitting him for his [inferior] position in life" (SANAC Report, 52; Bot, 1951: 158-159). The SANAC urged that government financial grants to African schools be given only on condition of a "satisfactory report by Government Inspectors as to the efficiency and conduct of the Native schools to be aided" (SANAC Report, 51).

This suggests that the content of education in mission schools had to be in line with the kind of sentiment Milner expressed. Indeed, just after the SAW, the content of education in mission schools came under severe criticism by white critics who perceived it to be the same as that of white education. They argued that mission education for Africans "had to adjust and conform to the economic and social roles which African people had to perform." Furthermore, mission education for the African was criticized because " it puffed him up,' making him disinclined for manual labour and an easy victim for agitators" (Cross, 1992: 130-131). It was against this background that in 1903, the Rev. W. E. Clarke was appointed to the newly created position of Inspector of Native Education in both the Transvaal and the Orange Free State in order to reorganize African education. Clarke worked under the Superintendent of Native Education. For mission education for black pupils, Clarke recommended to the government "a certain course of elementary and industrial instruction ..." Thus from 1905, it became compulsory for African 
teacher-trainees to train in the teaching of manual skills for African pupils in mission schools. In order to strengthen the implementation of the new curriculum, the government began to give grants from public funds to five mission institutions that trained African teachers (Cross, 1999: 58).

By the beginning of the Crown Colony period in South Africa (19021907), the nature and direction of African education was already taking shape. Thus, the Superintendent's Report for 1903, for example, recommended the teaching of English on an elementary level for the sake of "a common medium of communication between white employer and Native employee..." (Bot, 1951: 159; emphasis added. Cf Linington, 1933: 238).

On the basis of the foregoing racial thinking, in 1903, the Milner administration instituted new measures to regulate the administration of African education in the Transvaal. In 1903, for example, a Superintendent of Native Education as well as an Assistant Inspector were appointed. At the same time, a "scheme" for African education was introduced to give instruction in the three R's up to Standard III and encourage manual training (Bot, 1951: 158; TKP, Annual Report, 1903: A10). If a missionary society accepted this scheme, it would receive grants-in-aid from the government. While the German and DRC missions were opposed to this education scheme, it was not because it offered inferior education, but rather that it excluded the teaching of African languages -- which was the media of spreading the gospel (Bot, 1951: 159).

But, considering that African (mission) schools were run on a self-help basis, with meagre financial and material resources, the sort of "efficiency and conduct" reports required by the government Inspectors would have been difficult to achieve by the majority of such schools. Thus, by 1910 , the Pilanesberg schools, together with other mission schools in the western Transvaal, were still entirely self-supporting and had not yet got any grants-in-aid from the government by that stage. (TPP, Annual Report, 1910: 100). The "new" segregationist policy culminated in the Education Act of 1907 which entrenched and institutionalised segregated schooling that prevailed throughout the period addressed by this paper and after. ${ }^{6}$ It is significant to note that "only a few missionaries" were opposed to this scheme of segregated schooling. Many missionaries, in fact, accepted it "as a healthy division of labour and resources" (Cross, 1987: 268). It was because of these reasons that the Bakgatla had become disillusioned with mission education and decided to do something decisive about it.

The official emphasis upon 'industrial' and 'agricultural' training for African pupils resulted from the desire of colonial society to ensure that Africans served their interests. In the colonial setting, Africans could only

\footnotetext{
${ }^{6}$ For details of this policy and how it was implemented, see Cross, 1987: 268; Bot, 1951: 160 - 163.
} 
serve in subservient positions of performing manual labour. Andrew Patterson explains the objectives of industrial and 'agricultural' training for African pupils and students as follows: "Industrial and agricultural curriculum ideas referred essentially to low skill forms of education for Africans to participate in a segregated colonial society: their roles were defined for them in a largely rural environment" (Patterson, 2005: 380). Consequently, in the Transvaal, for example, the new curriculum, which was put into practice in 1915, made training its central aim and it included subjects such as religious and moral training. Boys were given what was euphemistically termed 'industrial training,' which encompassed gardening, rudimentary agriculture, basketmaking, mat-weaving, tree-planting and the care of trees. Girls were trained in, among other areas, sewing and domestic service, including cookery, kitchen work, laundry and other household-related work. Overall, such training for African pupils was "intended to develop habits and aptitudes which would enable the native to live a healthy life and render more effective service" (Cross, 1992: 131). Elsewhere in colonial Africa in the early $20^{\text {th }}$ century, the situation was very similar. In Bechuanaland, for example, mission education "included knitting, sewing and dressmaking, and the preparation of European foods ..." (Comaroff and Comaroff, 1997: 299).

Many missionaries themselves supported the idea and practice of 'industrial' education and expressed similar views to those of the colonial officials. They believed, for example, that because of its practical nature, 'industrial' education would contribute to Africans maintaining ties with their "traditional" context. Moreover, it was argued that an industrial curriculum was better-suited to their, presumably low, intellectual capabilities and needs. As the Rev. Wilder stated, missionaries "would not advocate producing artisans to compete with European mechanics, but should aim rather to prepare natives who would be able to supply the needs which come to a people rising out of savagery ..." (Patterson, 2005: 392). In other words, Africans were to be "trained for participating in a segregated colonial society in which their (inferior) roles were defined for them" (Ibid, 396-397).

The World Missionary Conference held in Edinburgh, Scotland, in June 1910 recorded among other agreements that: "The special purpose which educational missionary work serves in reference to missionary enterprise as a whole [is for] pupils to read the Bible and other devotional books for themselves, thus making accessible to them the literary sources of Christian truth and faith, found especially in the Scriptures." The Rev. L. Fuller who had attended the Edinburgh conference put it more explicitly. Speaking from Johannesburg about South Africa as a whole, he stated that even though missionaries had "done very good work," the "chief purpose" of missionary education "has been religious rather than educational" (World Missionary 
Conference, 1910: 183). Consequently, in the Transvaal specifically, a new curriculum was devised for schools and put into practice in 1915.

\section{DRC mission education in the Pilanesberg}

The teaching of the gospel went hand in hand with that of literacy and the rudiments of Western education. It was the gospel, however, that took precedence over all else. In the Pilanesberg mission schools, education consisted of the three Rs and Bible learning. There were two classes of Catechism, one in Setswana and the other in Dutch. After two years' instruction, a candidate for baptism was questioned orally in front of the whole congregation. Regarding the missionary purpose of education, the DRC missionary writer, W. L. Maree has put it succinctly: "The purpose of education is to develop understanding, empathy and to win the children for Jesus Christ" (Maree, 1966: 65-66; Seboni: 85: 5). Whereas at first church membership was based simply on one's willingness to join, by 1914, the Church Council proposed a new requirement: "a satisfactory knowledge of Bible history" and literacy in Setswana, except for the elderly (Notulen van de tweede zitting, 1914), thus stressing the importance of the link between literacy and the gospel. In all the mission schools for Africans, the emphasis was on religion (Simpson, 1986: 367-377; Strassberger, 1969: 24).

Perhaps even more revealing was the official view of the Transvaal Education Department which, as late at 1930, stated that mission schools for Africans "are regarded as ancillary to the religious activities of the missionary societies with which they are connected" (Transvaal Education Report, 1930). It was for this reason that "so far as formal education was concerned, little beyond the elements of reading and writing was taught" (Horrell, 1963: 23). In terms of the missionaries' purpose of education, they were making some progress. In 1897, for example, out of an estimated Saulspoort population of 5000 , some 800 had been baptised, while 400 merely attended church. ${ }^{7}$ In charge of the converts were two white female teachers M. Murray and M. Kriel, several other white teachers and five black teacher-evangelists (Maree, 1966: 88. 159). At the end of the 19th century, the DRC's evangelical progress in the Pilanesberg was best summed up by Gonin himself in the following manner:

....and now besides many outstations, we have amongst the people of that tribe [the Bakgatla], the three great stations of Sauls-Poort, Mochuli and Sikwane..., 12 - 1500 communicants and thousands of baptised children every Sunday. In several places the Gospel is heard by hundreds and hundreds of natives who for the most part are able to read the word of God in their own tongue and are

7 Heathens too, "except the bad ones," were welcome to attend prayers. See Dutch Reformed Church Archives (hereafter DRCA) S5/15/7/1, "Notulen van de Zendings Conferentie...," Saulspoort, 17-18 May 1888. 
pretty well-acquainted with their Bibles: in many homes family worship is held and Christian hymns are heard (Gonin to Murray, 29 August 1899).

By June 1903, the Pilanesberg as a whole had seven schools (apart from an undetermined number in the outstations) with a total pupil population of 560. That year, pupils paid between $6 \mathrm{~d}$ and $1 \mathrm{~s}$ per month as school fees (TKP, Annual Report, 1903). ${ }^{8}$ This money, little though it may seem now, was difficult for parents to get and, therefore, many prospective pupils stayed out of school (T. S. Pilane, personal communication, 8 October 1993; M.L. Pitse, personal communication, 29 May 1993). ${ }^{9}$ In 1905, Saulspoort alone had the largest school population in the Pilanesberg. It had 3 classes with a combined total of 272 pupils, taught by 3 teacherevangelists, Z. Phiri, J. Moitsi and J. Ramala who taught Catechism and the 3 Rs. The fees at the Saulspoort school were 1 Shilling per pupil per month, 5 Shillings annually or $6 \mathrm{~d}$ per month, depending on the class: the higher the class, the more the fees were. At the 'out-schools' of Modderkuil, Cyferkuil and Welgeval, it was 2 Shillings and 6 Pence per pupil annually, while at Ruighoek it was 1s per month (TKP, Annual Report, 1905: C81). ${ }^{10}$

With an average of 91 pupils per teacher, classes at Saulspoort were certainly overcrowded and the teaching loads must have been taxing. These very large classes reflected the equally large population of Saulspoort. While the entire farm was 3,925 morgen (Breutz, 1953: 245), the mission part alone, which was 642 morgen, for example, held some 2751 Africans in 1905 (TKP, Annual Report, 1905: C88). The smaller DRC out-schools with a combined school population of 249 and a much smaller average class size of 50, were on the farms, Modderkuil, Cyferkuil, Welgeval, Ruighoek and Palmietfontein. In the rest of the Pilanesberg, there was a much smaller number of schools run by the Lutherans at Grootwagendrift, Bultfontein, Ramokokaskraal and Grootfontein, while the Wesleyans and the Church of England were at Mabeskraal and Bierkraal, respectively.

An outstanding feature of the Pilanesberg/Rustenburg schools, like the church congregations, was that generally, females far outnumbered males. An extreme example was a Saulspoort class of 1906 with 50 girls and only 1 boy. ${ }^{11}$ This general sex-ratio imbalance in the Pilanesberg schools continued up to the 1920s. As the SNC reported in September 1926, for instance, girls outnumbered boys "by about $75 \%$ to $25 \%$ in the higher classes" (Kommisaris

\footnotetext{
8 TKP, Vol. 239, Annual Report by the Commissioner for Native Affairs, Transvaal, 30 June 1903, Appendix 28.

${ }^{9}$ Ms Pitse completed Standard Six at Ramolope School, Saulspoort, in 1927.

${ }^{10}$ The reasons for these fee differences in the outer-schools are not clear. But they may reflect the different levels of the individual communities' ability to pay.

${ }^{11}$ SNA 6, NA 519/02, Annual Report, 30 June, 1906, Appendix 9, C.101; Schapera, 1938: 28 - 29.
} 
Pilanesberg, 1926: 6). In Bethanie's Hermannsburg mission schools, the situation was similar (Simpson, 1986: 378-379). This heavy preponderance of females in school and church is explained by the fact that the males spent most of their time tending cattle at cattle-posts too far away from the villages or were outside the region on wage-labour (ibid; Schapera, 1938, 28-29; 1958: 3,7).

Until after the SAW, these mission schools did not receive any government grants and were therefore entirely self-supporting. The construction and maintenance of the schools, like the churches, was borne by the local Christian community, including those working away from home, who contributed money or unpaid labour. In 1888, for example, Saulspoort's congregation members working on the diamond fields at Kimberley contributed $£ 22$ towards the building of a new church (Maree, 1966: 66; Schapera, 1958: 3). Teachers' salaries, in 1906, of between $£ 18$ and $£ 48$ per annum (SNA, Annual Report, 1906: 101), were probably partly contributed by the community as well. Some indication of this is the fact that as late as 1934, for example, the DRC decided that the Sunday schools were to pay for the Saulspoort mission station (Maree, 1966: 226). ${ }^{12}$ There is no evidence of a medical facility at any DRC mission in the Pilanesberg in the period up to the 1920s. But Church policy regarding medical work was spelt out in 1909 when the DRC's General Mission Secretary, A.C. Murray, stated that the African's "first and greatest need," was conversion and stressed that medical work was only secondary to the major missionary objective of evangelisation. Medical work was, he bluntly stated, "not an end in itself, but a means to an end, the end being winning souls for Christ" (Murray, 1909: 24. 26). Thus, due to this policy, even as late as 1935, Saulspoort still had "no medical station" and, following representations by chief Ofentse to the Native Affairs Department (NAD) and the DRC, the latter agreed "to arrange for the Mission doctor at Mochudi to visit Saulspoort once a month, and to provide a resident nurse at Saulspoort at their own expense" (SNA to Minister of Native Affairs, 1935) ${ }^{13}$

The emphasis on self-support was a feature of the majority of African mission schools in South Africa during the first three decades of the 20th century. At Anglican missions in the Transvaal at the beginning of this century, for example, the salaries of black evangelists were borne entirely by their own congregations (Agar-Hamilton, 1928: 127). Patterson has recorded that by the end of the 19th century, missionaries began to insist upon dependence on local resources to sustain African mission churches and schooling because of the diminishing of metropolitan revenues. This in turn, he argues, led to the division of financial resources on racial lines, with black priests and catechists

\footnotetext{
${ }^{12}$ It is not clear, however, whether this decision was carried out.

${ }^{13}$ There were problems of lack of facilities, however, and the erection of "two huts" to serve as a "medical station" began only in July 1935. In the same file, see "Erection of two huts on the mission property at Saulspoort..."
} 
getting substantially lower wages than their white colleagues (Patterson, 1993:114-115). ${ }^{14}$

By the 1920s in the Transvaal, the government was paying a grant towards each certificated teacher at an "approved" school under a whitemissionary and a "small sum" for equipment, while the rest of the expenditure was met by parents (Agar-Hamilton, 1928: 135). This inadequacy of government funding, which was common to all mission schools, resulted in poor facilities and, of course, poor education. ${ }^{15}$ By August 1931, the church's three school-buildings on Saulspoort were in a such a state of disrepair that the Inspector of Native Education for the area, N. D. Achterberg, had this to say about them: "Neither of the three buildings is suitable as a schoolbuilding...; the second building is only suitable as a pigsty; while the third building (the one furthest away) is a typical church building, with bad lighting and worse ventilation" (ibid).

Achterberg recorded further that the buildings were "too small," "badly ventilated," "badly lighted," "badly constructed" and made "satisfactory teaching practically an impossibility." He, therefore, "strongly [recommended]" to the government's Native Affairs Department for the Bakgatla to be assisted in erecting a "decent school-building" (Achterberg to NC, 22 August 1931). It was only from the end of 1931, partly through the missionary George Stegman's spirited pleas to the Sub-Native Commissioner, that the government came in to assist in the construction of the first properly built school at Saulspoort, which was completed in 1937. But even in this instance, the Bakgatla had to get a "grant" of $£ 600$ from their own money in the Native Development Fund to finance the project (Achterberg to NC, 22 August 1931). The Bakgatla made considerable efforts to improve their poor and inadequate educational facilities. On two of their properties, Modderkuil and Witfontein, during the late 1920s, for instance, they gathered foundation stones "from six miles distance" and erected a school-building "capable of seating 200 children." However, as they ran out of resources and failed to pay for the roofing, doors and windows, they appealed to the NAD for support (Stegman to SNC, 22 December 1930). In August 1931, the Saulspoort Bakgatla decided to erect "a very big building" for classrooms on their location because the existing buildings were "too small and unhealthy to (sic) the children." The Bakgatla took the initiative and made 80000 bricks themselves before they requested the government for more assistance

\footnotetext{
${ }^{14}$ In contrast to the great majority of mission schools for Africans with meagre resources that were battling for survival, there were a few elite-type mission schools for a relatively small number of Africans, such as Tigerkloof, Lovedale, Healdtown and St. Matthews which "were financially well-supported by the home churches, staffed and controlled in the majority by white missionaries and usually endowed with extensive teaching facilities and boarding accommodation." See this source, p. 83.
}

${ }^{15}$ For the period under review, see A.G. Smurthwaite, 1975: 120-132. 
(Pilane to Assistant Native Commissioner, 25 August 1931). This physical neglect was only part of the problem and dissatisfaction the Bakgatla had with missionary education and which, as we will see shortly, motivated them build their own school.

Much more important to the Bakgatla was the question of the content of mission education with which, by the late 1910s, they had become increasingly dissatisfied. However, before we discuss the kind of initiatives the Bakgatla took to remedy what they saw as a defective mission school curriculum, we first need to look briefly into the official background policy and practice regarding African education in the Transvaal in order to better appreciate the sort of actions the Bakgatla took.

\section{The Bakgatla's alternative educational model}

The missionary emphasis on the religious component of the curriculum at the expense of other subjects began to cause dissatisfaction among literate and educated Bakgatla. They wanted, for example, much more English and Science to be taught, contrary to the General Missionary Conferences of 1904, 1906 and 1909, which had adopted the policy that in the lower standards of African education, teaching should be in the African local language (TPP, Annual Report, 1910: 100). But, as the Sub-Native Commissioner for the Pilanesberg reported in 1910, this was precisely what the Bakgatla were against: "The natives deplore the fact that so little English is being taught in the schools." 16 Another Bakgatla grievance up to the early 1920s was that the DRC mission school in Saulspoort, like all mission schools for Africans in the Transvaal, had only Standard 3 as its highest educational level (Loram, 1917: 63). For higher levels, Bakgatla pupils usually went to the Bakgatla National School in far away Mochudi, Bechuanaland (Pilane, personal communication, 8 October 1993). ${ }^{17}$ One scholar, Summers, has recorded similar African dissatisfaction with education in DRC schools in the Gutu area of Southern Rhodesia during the 1920s and 1930s. According to Summers, "DRC schools [in Southern Rhodesia] were notorious for failing to satisfy Africans who came to school wanting to learn English and acquire an education which would lead to a better job" (Summers, 1994: 8). ${ }^{18}$

The Bakgatla on both sides of the border between the Transvaal and the British Bechuanaland Protectorate (now the Republic of Botswana) began to clamour for the broadening of the missionary curriculum. But when a Mochudi teacher, A. K. Pilane, took up the issue with the local DRC

\footnotetext{
${ }^{16}$ For details of this policy and how it was implemented, see Cross, 1987: 268 and Bot, 1951: 160 - 163.

${ }^{17}$ This informant did Standards 4 - 6 there, from 1924. Members of the Bakgatla royal family were generally educated there before they proceeded to the prestigious missionary institutions, such as Tigerkloof.

${ }_{18}$ Dissatisfaction was so strong that attendance at DRC schools in the area dropped drastically as pupils obtained alternative schooling at Zionist Church schools. For details, see Summers, 1994: 6 - 14.
} 
leadership, the Rev. A.C. Murray told him that he (the missionary) was there "to teach the Kgatla people the word of God, not the wisdom of the world" (Pilane, 1973: 120). Not content with the rebuff, the Bakgatla appealed to the DRC's Home Committee in Cape Town, whose reply Pilane expressed quite starkly: "[T]he words of the Rev. Murray were repeated; they [missionaries] did not want worldly subjects like arithmetic to be taught" (ibid). It was due to this grievance that during the decade preceding the First World War, one S. Pilane began running 'tribal' schools in Mochudi. There were similar efforts among the neighbouring Bakwena and Bangwaketse in Bechuanaland who, as early as 1908, had launched their own "national schools" (J.F. Ramsay, personal communication, Gaborone, Botswana, 29 April 1996). In 1920, as a continuation of these efforts, the then acting paramount chief of the Bakgatla, Isang Pilane, transferred control and responsibility over Bakgatla education from the DRC to a "tribal" committee, but on which both the church and the British administration were represented (Schapera, 1935: 55). Subsequently, the Protectorate Bakgatla, led by Chief Isang, built their own "Bakgatla National School" in Mochudi in 1923, in order to provide the kind of education that they desired.

Mochudi's idea of a national school idea appealed strongly to the Pilanesberg Bakgatla as well. After all, they faced similar problems regarding missionary education. In the Pilanesberg, the initiative to build such a school came from the Molope family of Saulspoort, led by their patriarch, Cornelius. ${ }^{19}$ The school, named "Ramolope," after the Molope family, opened in the early 1920s with about 15 pupils, all of them members of this family, and most of whom had left the DRC schools. The Ramolope school was built entirely on a self-help basis. The school's only teacher at its inception was J. J. Molope, also a member of the Molope family. ${ }^{20}$ While the missionaries only taught the Bible, Afrikaans and the 3 Rs, with emphasis on the former, the new school offered much more of English lessons as well as Arithmetic, a fact which made the school very popular.

The missionaries, of course, did not like this competitive situation and their worst fears were confirmed when some of their pupils "left the mission school and flocked to this [new] school." The missionaries expressed their verbal opposition to the existence of this "Bakgatla school," but did not take any practical measures against it, out of the fear of alienating popular Bakgatla opinion. Nevertheless, the matter upset the missionaries to the extent that they "excommunicated all adult members of the Molope family," presumably for

\footnotetext{
19 The rest of this discussion on the self-help Ramolope School is based on interviews with Ramurula Molope, Simon Molope and Moitoi Lydia Pitse, Saulspoort, 29 May 1993. Both Molope and Pitse attended the school.

${ }^{20}$ John Jonathan's father, Montsu Molope, had been "kidnapped" by the Boers from his Saulspoort home and taken to Potchefstroom at the beginning of the South African War. Montsu "worked for the Boers" in Potchefstroom, married there and had a son, John Jonathan, who later trained as a teacher at Lovedale. Meanwhile, Montsu Molope had left a brother in Saulspoort who later became an itinerant general trader. During one business trip to Potchefstroom, he met by chance with his long-lost brother, Montsu. On reporting the encounter to relatives back in Saulspoort, the young John Jonathan was persuaded to "return" and teach in the new "Bakgatla[i.e. 'Ramolope'] school" in Saulspoort. In the words of M.L. Pitse, J.J. Molope was "the first person who brought light [i.e. education] in this area."
} 
having started the school in the first place and the fact that some mission pupils were now joining Ramolope School. The school became so popular that the rest of the Saulspoort community joined in the initiative. As the pupil population of Ramolope began to expand in the mid-1920s, four more teachers joined the school (J.J. Molope was now the school's principal). ${ }^{21}$ It should be emphasised that by the late 1920s, the Ramolope School, despite its name, was no longer simply a family enterprise, but had developed and expanded into a community project serving the wider Bakgatla populace. The annual tuition fees, teachers' salaries and all administrative costs were paid monthly, entirely by the parents. In 1927, the school had its first Standard 6 class, the highest school level in the Pilanesberg throughout the 1920s. The academic standards at Ramolope must have been quite high because the following year, 1928, some of the school's 1927 graduates went for further education and training at the famous missionary institutions, such as Kilnerton, Lovedale and Tigerkloof. ${ }^{22}$

Both Ramolope and the mission school experienced growth, but in different directions. The latter's growth, with its emphasis on Bible teaching, was almost entirely spiritual while the former's was secular, with a practical, yet academic, emphasis on producing candidates who would proceed for further education and training. In this respect, which was its objective, Ramolope School was singularly more successful than the DRC school. Perhaps because of this success, the missionaries' earlier jealousy of, and opposition to, the school had ceased by the 1930s. With expansion, the school needed larger premises and was shifted to central Saulspoort.

But expansion also meant that the community found it more and more difficult to meet the school's routine overhead costs. It was, therefore, taken over by the government at the end of the 1930s and renamed "Ofentse," in honour of then acting chief Ofentse (1922-1942) who actively gave financial and material support to the school. By this time, Ramolope had ceased to be simply a Bakgatla school and become an important regional institution, attracting pupils from all over the Pilanesberg. However, it should be noted that the Bakgatla's establishment of Ramolope School was not unique to them only. In the rest of the Transvaal during the 1920 s, there was a number of such schools, an indication that other African communities had similar problems and concerns. A Transvaal Education Department report for 1930, for example, recorded that "there is a large number of private schools -- probably between 200 and 300 -- run by the natives themselves..." (TPP, Transvaal Education Department Report, 1930: 21).

\footnotetext{
${ }^{21}$ Three of them were Moses Mokae, Tihira Raletlhokoa and Ramogaritsi Pilane, all from the Pilanesberg. My informants could not remember the name of the fourth.

22 From that pioneer class alone, about 8 students, 3 of them female, trained as teachers at these institutions.
} 
But this does not in any way diminish the importance of this development among the Bakgatla. It was significant for a number of reasons. First, the Bakgatla had demonstrated that they did not have to wait for missionary or any other outside initiative to undertake a venture of this kind. While the many DRC outstation schools in the Pilanesberg had been started by black teacher-evangelists, it was at the behest of the missionaries. This time, however, it was the Bakgatla's own initiative. But even the fact that the school was started by a family, rather than the community, was in itself unique. Second, the school was a clear manifestation of the Bakgatla's dissatisfaction with the mission school curriculum and also a demonstration of their ability to remedy what appeared to be a hopeless situation. They determined their own curriculum, according to their own objectives and achieved them. Third, the dissatisfaction with mission education implied that the Bakgatla, at least the literate and educated ones, had, by the 1910s, become conscious of the value and practical benefits of the kind of education they wanted their children to have.

The Bakgatla, as we will see below, were not alone in creating their own school as a way of protesting against what they saw as an unsatisfactory and unacceptable kind of education in the mission schools within their areas. In the Transkei in the early 1920s, for example, Africans founded and ran their own schools, distinct from and in opposition to those of the missions and the government. The influence upon Africans taking this route came from the ideas of the early $20^{\text {th }}$ century African-American intellectual, Marcus Garvey, who called for the upliftment and liberation of black peoples everywhere; the renaissance and reassertion of black culture and values; the material advancement and unity of blacks. In the early $20^{\text {th }}$ century in the Transkei, the leading propagator of these ideas was one Elias Wellington Buthelezi. ${ }^{23}$ Influenced by these ideas of black liberation and independence from mission schools and Christian ideology, Buthelezi founded an independent church with its own school, arguing that:

to break this monopoly Africans should establish and control their own schools and churches so that their children could be brought in institutions which reflected and preserved African values. Teachers and the curriculum were to be under the control of the people, not foreign agents. (Edgar, 1984: 186)

Buthelezi's own school was called St. Booker Washington Memorial Industrial Liberty College, close to Edendale, Natal. By 1930, Buthelezi claimed he

${ }^{23}$ Born near Melmoth, Natal, in c.1895, Buthelezi was educated at Mapumulo Training Institute and, for a year, at the famous Lovedale Institution. In the mid-1920's, having worked at a variety of jobs, he settled down as a representative of Marcus Garvey's Universal Negro Improvement Association (UNIA). This African-Americaninspired movement had taken root in South Africa after the First World War. For details, see Edgar, 1984: 184 - 185. 
had opened well over 100 schools and some 200 independent churches in northeastern Transkei and eastern Griqualand.

The foregoing African activities were responses to European colonialism and domination, racism generally, and the white missionary thrust onto the African continent specifically. The subsequent Ethiopian religious movement which emerged in Africa towards the end of the $19^{\text {th }}$ century was an expression of African responses to the call from Garvey. It was also a demonstration by Black peopleof their self-worth in the face of cultural imperialism by the European world. The Ethiopian movement was strongly influenced by the Pan-African movement of Marcus Garvey and another African-American intellectual, W. E. B. Dubois. This movement asserted and promoted self-reliance and self-improvement of Africans world-wide. For this purpose, in 1914, Garvey founded the Universal Negro Improvement Association. On the continent itself, the foregoing Pan-Africanist ideas, spirit and thought were promoted and propagated by luminaries like James Blyden in Liberia, John Chilembwe in Nyasaland, Mpambani Mzimba and Nehemia Tile in South Africa (Duncan, 2015).

We have no direct link between the Bakgatla's founding their own school and the Garveyite movement and influence from the Transkei. However, we do know that shortly after the First World War, Garveyite disciples "had gradually spread Garvey's ideas to the rural areas through returning migrants or by word of mouth and rumour ..." (Duncan, 2015: 185). It is also certain that in the Pilanesberg just after the SAW, white missionaries in the area complained of what they saw as the proliferation of Ethiopian churches, whose ideology of African emancipation and independence resonated with that of Garvey. It is quite plausible that such ideas and influence could have permeated from the Transkei through to the Pilanesberg. In August 1899 in Phokeng, just west of the town of Rustenburg, the Hermannsburg Mission Society missionary based there, Ernst Penzhorn, reported about the independent church movement which, he complained, was hampering the advancement of his missionary work. Penzhorn wrote as follows:

A particular danger approached last year. That is through the penetration of a Methodist sect, which calls itself the Ethiopian church. It tries to infiltrate our neighbouring stations from Pretoria, with strong words of seduction. It is their intention to alienate the Christian communities from the influence of the missionaries and the whites as a whole (Mbenga and Mason, 2010: 52).

Just after the SAW when Gonin returned from furlough in Switzerland to his mission station in the Pilanesberg, he found a new phenomenon that disturbed him. Among the Bakgatla generally, including his own congregation, Gonin observed a spirit of independence that made him uncomfortable and he 
recorded the following:

The natives [i.e. Bakgatla] cherished high expectations created by the advent and many wished that the teaching of English should be the main priority in schools. In addition, the influence of the Ethiopian sect in striving for the cultivation of African independence as opposed to white domination, received an effective expression ... Ever since the war, the spirit of wickedness overcame the natives; their strong desire for everything English. They believed that they could stand alone on their own feet and that they no longer required the services of the white missionaries (Maree, 1966: 142).

From all the foregoing, we can see and understand why and how the Bakgatla, being disillusioned by the sort of education their children were getting from the DRC missionaries, decided to embark upon a different and superior education for them. 


\section{References}

Achterberg, N.D. to Native Commissioner, 22 August 1931. Native Affairs Files (NTS) 2815, NA 180/302. South Africa National Archives (SANA), Pretoria.

Agar-Hamilton, J.A.I. (1928). A Transvaal Jubilee, Being a History of the Church of the Province of South Africa in the Transvaal. London: Society for Promoting Christian Knowledge.

Bot, A.K. (1951). The Development of Education in the Transvaal, 1836 1951. Pretoria: Transvaal Education Department.

Breutz, P-L. (1953). The Tribes of the Rustenburg and Pilanesberg Districts. Pretoria: Native Affairs Department.

Comaroff, J.L. and Comaroff, J. (1997). Of Revelation and Revolution, Vol. II, The Dialectics of Modernity on a South African Frontier. Chicago and London: University of Chicago Press.

Comaroff, J.L. (1989). Images of empire, contests of conscience: models of colonial domination in South Africa, American Ethnologist. 16(4).

Comaroff, J.L. (1991). Missionaries and mechanical clocks: an essay on religion and history in South Africa. American Ethnologist, 16(1).

Cross, M. (1987). "The foundations of a segregated schooling system in the Transvaal, 1900 - 1924. History of Education. 16(4).

Cross, M. (1992). Resistance and Transformation: Education, Culture and Reconstruction in South Africa. Johannesburg: Skotaville Publishers.

Cross, M. (1999). Imagery of Identity in South African Education, 1880 1890. Durham: Carolina Academic Press.

Dachs, A.J. (1972). Missionary imperialism - the case of Bechuanaland. Journal of African History, 13(4).

du Toit, B.M. (1984). Missionaries, anthropologists and the policies of the Dutch Reformed Church. The Journal of Modern African Studies, 22(4).

Duncan, G. A. (2015). Ethiopianism in Pan-African Perspective, 1880 1920. Studia Historiae Ecclesiasticae, 41( 2).

Dutch Reformed Church Archives (DRCA), S5/15/7/1, "Notulen van de tweede zitting...," Johannesburg, 6 October 1914.

Edgar, R. (1984). African educational protest in South Africa in the 1920s. In P. Kallaway (Ed.), Apartheid and Education: The Education of Black South Africans. Johannesburg: Ravan Press.

Elphic, R \& Davenport, R. Christianity in South Africa : A political, social and cultural history. Cape Town: David Philip.

Fast, H.H. (1991). African perceptions of missionaries and their message: Wesleyans at Mount Coke and Butterworth, 1825-1835. MA dissertation, University of Cape Town. 
Gonin, H. L. to Murray, 29 August 1899. S5/15/7/2. DRCA.

Grant, S. (1984). The revival of bogwera in the Kgatleng - Tswana culture or rampant tribalism? Botswana Notes and Records, 166.

Hofmeyr, I. (1991). Jonah and the swallowing monster: orality and literacy on a Berlin mission in the Transvaal. Journal of Southern African Studies. 17(4).

Horrell, M. (1963). African Education: Some Origins and Developments

Until 1935. Johannesburg: South African Institute of Race Relations.

Hutchinson, B. (1957). Some social consequences of nineteenth century missionary activity among the South African Bantu. Africa, 27(2).

Jordaan, J. T. (1962). "Die Ontwikkeling van die Sending van die Nederduits

Gereformeerde Kerk in Transvaal," D.D. thesis, University of Pretoria.

Kommisaris Pilanesberg, N1/15/6, «Native Administration Report, 1922-

1925,» by SNC, Rustenburg, 30 September 1926, p. 6.

Loram, C.T. (1917) The Education of the South African Native. London: Longmans, Greens \& Co.

Linington, P.A. (1933). Native Administration in the Republic of South Africa. Pretoria: Government Printer.

Maree, W.L. (1966). Uit Duisternis Geroep, Die Sending werkvan die Nederduitse Gereformeerde Kerk onder die Bakgatlavolk van Wes-Transvaal en Betsjoeanaland, Voortrekkerpers, Johannesburg. Marks, S. (2011). War and Union. In R. Ross, A. K. Mager and B. Nasson (Eds.). The Cambridge History of South Africa, Vol. II, 1885 - 1994. London: Cambridge University Press.

Mbenga, B. (1996). The Bakgatla ba ga Kgafela in the Pilanesberg District of the Western Transvaal, from 1899 to 1931. D. Litt. et Phil thesis, University of South Africa.

Mbenga, B. and Manson, A. (2010). A History of the Bafokeng of the Phokeng-Rustenburg District, South Africa, From Early Times to 2000. Johannesburg: Jacana Media.

Murray, A. C. Missionary pioneer policy. Report of the Proceedings of the Third General Missionary Conference for South Africa, Bloemfontein, 1- 6 July 1909. Dutch Reformed Church Archives, SEN5 (P) 1/2.

Native Administration Report, 1922-1925. Sub-Natïve Commissioner, Rustenburg, Kommisaris Pilanesberg, N1/15/6, 30 September 1926. Patterson, A.N. (1993). Contest and co-option: the struggle for schooling in the African independent churches of the Cape Colony, c.1895-1920. D. Phil. thesis, University of Cape Town.

Patterson, A. (2005). 'The gospel of work does not save souls': conceptions of industrial and agricultural education for Africans in the Cape 
Mlbenga, B. K./ Dutch Reform Church Mission Education and its Secular Reconstraction/Transfotmation

Colony. History of Education Quarterly. 45(3).

Pilane, A.K. (1973). Notes on early educational efforts... Botswana Notes and Records, 5.

Pilane, O. to Assistant Native Commissioner, the Pilanesberg, 25 August 1931. NTS 2815, NA 180/302. SANA

Rotberg, R. (1965). Christian Missionaries and the Creation of Northern Rhodesia 1880-1924. New Jersey: Princeton University Press.

Schapera, I. (1938). Handbook of Tswana Law and Custom. London: Oxford University Press.

Schapera, I. (1934). Present-day life in the Native Reserves. In Schapera,

I. (Ed.). Western Civilization and the Natives of South Africa.

London:Routledge.

Schapera, I. (1942). A History of the Bakgatla-baga-Kgafela of the

Bechuanaland Protectorate. Cape Town: University of Cape Town.

Schapera, I. (1958). "Christianity and the Tswana," Journal of the Royal Anthropological Institute, 83.

Secretary for Native Affairs (SNA) 6, NA 519/02, Annual Report, 30 June, 1906, Appendix 9, SANA.

SNA to Minister of Native Affairs, n.d., 1935. Files of the Department of

Bantu Administration \& Development (BAO), Vol. 2218, Native Affairs (NA) 130/303, SANA

Simpson, G.N. (1986). Peasants and politics in the Western Transvaal, 1920

- 1940. MA dissertation, University of the Witwatersrand.

Smurthwaite, A.G. 1975. The policy of the Smuts Government towards Africans, 1919-1924. MA dissertation, University of South Africa.

South African Native Affairs Commission (SANAC) Report, p. 52.

SANA. Stegman, G.P. to SNC, the Pilanesberg, 22 December 1930.

NTS 2815, NA 180/302. SANA

Summers, C. (1994). Educational Controversies: African Activism and

Educational Strategies in Southern Rhodesia. Journal of Southern

African Controversies, 20(1), 3-25.

Transvaalse Koloniale Publikasies (TKP) Vol. 239, Annual Report by the

Commissioner for Native Affairs, Transvaal, 30 June 1903, SANA.

TKP Vol. 239, Annual Report for the Year Ended June 1905, SANA.

TKP, Vol. 239, The Transvaal Education Report, 31 December 1930, SANA. Transvaal Provincial Publications (TPP), Vol. 6/1 Ref. 3, Annual Report, 31 May 1910, Appendix 9, SANA.

TPP, Vol. 6/10, The Transvaal Education Department Report, 31 December

1930, SANA.World Missionary Conference, 1910: Report of

Commission III: Education in Relation to the Christianisation of National Life. Edinburgh \& London: Oliphant, Anderson and Ferrier. 